\title{
KLOTHO and VDR Gene Polymorphisms and Clinical Phenotype in Chronic Kidney Disease Patients
}

\author{
Kronik Böbrek Hastalarında KLOTHO ve VDR Gen Polimofizmleri ve Klinik Fenotip
}

\section{Kuyaş Hekimler Öztürk ${ }^{1}$, Saliha Handan Yıldız ${ }^{1}$, Necat İmirzalıoğlu² ${ }^{2}$ Serap Demir ${ }^{3}$, Tülay Köken ${ }^{4}$, Memnune Sena Ulu ${ }^{5}$}

\begin{abstract}
${ }^{1}$ Department of Medical Genetics, Faculty of Medicine, Süleyman Demirel University, Isparta, Turkey
${ }^{2}$ Genetic Diagnosis Centre, HRS Women Hospital, Ankara, Turkey

${ }^{3}$ Department of Internal Medicine, Faculty of Medicine, Mersin University, Mersin, Turkey

${ }^{4}$ Department of Biochemistry, Faculty of Medicine, Afyon Kocatepe University, Afyonkarahisar, Turkey

${ }^{5}$ Department of Internal Medicine, Faculty of Medicine, Afyon Kocatepe University, Afyonkarahisar, Turkey
\end{abstract}

\section{ABSTRACT}

Objective: With an increasing incidence and prevalence, Chronic Kidney Disease (CKD), is a bad prognosed and high cost common public health problem. KLOTHO gene which is defined as aging suppressor gene is highly expressed in kidneys. Decreased Vitamin D receptor (VDR) activation plays a role in CKD morbidity and mortality. The aim of this study is to examine the association between CKD and polymorphisms of KLOTHO (G395A and C1818T) and VDR (Apal and Taql) genes as well as investigating the effects of these polymorphisms on different clinical phenotype of the disease.

Methods: In 104 cases diagnosed to have CKD and 104 healthy controls, KLOTHO gene G395A, C1818T polymorphisms were studied by DNA sequence analysis and VDR gene Apal and Taql polymorphisms were studied by polymerase chain reaction-restriction fragment length polymorphism (PCRRFLP) method.

Results: No statistical difference was found in genotype and allele frequencies for KLOTHO gene G395A, C1818T and VDR gene Taql polymorphisms between the groups. VDR gene Apal polymorphism was found to be significantly higher in the patient group than in the control group $(p=0.018)$.

Conclusion: Our results demonstrated that VDR gene Apal polymorphism may be related to CKD and may be a risk factor for the development of the disease.

Key Words: Chronic Kidney Disease, KLOTHO, VDR, Polymorphism.

Received: 01.11.2017
Accepted: 05.02.2018
ÖZET

Amaç: Kronik böbrek hastalığı $(\mathrm{KBH})$, insidansı ve prevalansı giderek artan kötü prognozlu ve yüksek maliyetli yaygın bir halk sağlığı problemidir. Yaşlanmayı baskılayıcı gen olarak tanımlanan KLOTHO geni, böbreklerde fazla miktarda eksprese olmaktadır. Azalmış vitamin D reseptör (VDR) aktivasyonu, KBH'nın morbidite ve mortalitesinde rol oynamaktadır. Bu çalışmada, $\mathrm{KBH}$ ile KLOTHO geni G395A ve C1818T polimorfizmleri ve VDR geni Apal ve Taql polimorfizmleri arasındaki ilişkiyi ortaya koymak amaçlanmıştır. Ayrıca, kronik böbrek hastalığının farklı klinik fenotipleri üzerine bu polimorfizmlerin potansiyel etkisini araştırmak amaçlanmıştır.

Yöntem: KBH tanısı almış 104 hasta ve 104 sağlıklı kontrol grubunda KLOTHO geni C1818T ve G395A polimorfizmleri DNA dizi analizi, VDR geni Apal ve Taq polimorfizmleri ise polimeraz zincir reaksiyonu-restriksiyon fragment uzunluk polimorfizmi (PCR-RFLP) yöntemiyle çalışılmıştır.

Bulgular: KLOTHO geni C1818T, G395A ile VDR geni Taql polimorfizminin genotip ve alel frekansı açısından hasta ve kontrol grubu arasında istatistiksel fark saptanmadı. Ancak VDR geni Apal polimorfizmi hasta grupta kontrole kıyasla anlamlı derecede yüksek bulundu ( $p=0.018)$

Sonuç: Bulgularımız, VDR geni Apal polimorfizminin KBH ile ilişkili olabileceğini ve KBH'nın gelişmesi için bir risk faktörü olarak davranabileceğini göstermiştir.

Anahtar Sözcükler: Kronik Böbrek Hastalığı, KLOTHO, VDR, Polimorfizm.

Geliş Tarihi: 11.01.2017

Kabul Tarihi: 02.05.2018

This study had been presented on XIV. Medical Biology and Genetics Congress, October 26-30th 2015, Fethiye, Turkey 


\section{INTRODUCTION}

Chronic kidney disease (CKD) can be defined as the chronic and progressive deterioration of metabolic-endocrine functions and renal fluid-solute balance functions depending on the decrease in the glomerular filtration rate (GFR) (1). In many studies it is reported that, chronic kidney disease susceptibility genes affect prognosis of the disease together with the environmental and hereditary factors (2).

KLOTHO is defined as the 'aging suppressor gene' which fastens the aging when it is deteriorated and which increases the life spans when it is excessively expressed in mice (3). Klotho protein is expressed mostly in spiral distal tubular cells of the kidney and choroid plexus of the brain. Moreover, it is also expressed in various endocrine organs such as pituitary gland, parathyroid, pancreas, ovary, testes and placenta (2). There are more than 10 mutations or SNPs of the human KLOTHO gene which were reported by population-based studies (4). It has been stated that G395A (rs1207568), which is localized in the promoter, is associated with bone mineral density, osteoarthritis, systolic blood pressure, atherosclerotic coronary artery disease, early vascular dysfunction and cardio embolic episodes (4). Other SNP C1818T (rs564481), which is localized in the exon 4 , is associated with bone mineral density, fasting glucose, atherosclerotic coronary artery disease $(5,6)$.

Vitamin $D$ receptor (VDR) protein is one of the members of the nuclear hormone receptor family. VDR protein regulates the vitamin $D$ hormone which has the central role in the endocrine system and bone-calcium balance (7). It has been specified that vitamin $D$ and vitamin $D$ analogues have kidney protective roles in CKD (8). Meanwhile, they also lead to positive effects via decreasing the risks of diabetes, autoimmune diseases, cancer and cardiovascular morbidity and mortality (9). In various studies which have been performed untill now, three adjacent polymorphisms such as RFLPs Bsml (rs1544410), Apal (rs7975232) and Taql (rs731236) have been emphasized which are located respectively in the $3^{\prime}$ end of the VDR gene, intron 8 and exon 9 (10). Some researchers found that VDR gene Taql polymorphism was associated with T1DM (Type 1 Diabetes Mellitus) whereas others did not detect any relationship with VDR gene and osteoporosis, T2DM (Type 2 Diabetes Mellitus) and breast cancer $(11,12,13,14)$. Similarly, there is an association with Apal polymorphism and epithelial ovarian cancer, however there is no relationship with osteoporosis, T1DM and T2DM $(11,12,13,15)$. Furthermore, it was also stated that there was a relationship between the Apal polymorphism, the aa genotype and the elevated PTH, osteocalcin levels, changes in calcium level, regulation of the PTH secretion in predialysis patients (16).

The aim of this study is to determine the incidence of G395A and C1818T polymorphisms of KLOTHO gene and Apal and Taql polymorphisms of Vitamin $D$ gene between case and control groups and to establish the relationship between corresponding polymorphisms and chronic kidney disease. Moreover, this study aims to investigate the potential effects of these SNPs on different clinical phenotype of chronic renal disease.

\section{METHODS}

\section{Study subjects}

The study protocol was in accordance with the Declaration of Helsinki and was approved by the Ethics Committee of the Kırıkkale University Faculty of Medicine. During the study period we enrolled 104 pre-dialysis chronic renal disease patients (49 female and 55 male; mean age: $56.76 \pm 1.22$ ) and 104 healthy controls (69 female and 35 male; mean age: $49.13 \pm 1.00$ ) from the Department of Internal Medicine, Afyon Kocatepe University Research and Application Hospital. Written informed consent was obtained from all participant patients. Subjects were evaluated for complete blood count, sedimentation, CRP, renal function test, fasting glycose, $\mathrm{HbA1c}$, total cholesterol levels, HDL cholesterol, LDL cholesterol, VLDL, triglyceride, TSH, Parathyroid hormon besides to age, gender, BMI, systolic and diastolic blood pressure. BMD of left forearm was measured using dual-energy X-ray absorptiometry.

\section{DNA extraction and genotyping}

Genomic DNA was isolated from whole blood samples using a commercially available DNA extraction kit (Roche, High Pure PCR Template Preparation Kit) according to the manufacturer's instructions. Analysis of KLOTHO gene G395A and $\mathrm{C} 1818 \mathrm{~T}$ polymorphism were performed by DNA sequence analysis. The following primer sets were used for the SNPs of the KLOTHO gene; C1818T F: 5'-TTACCTGTGGGATGTCCACCA-3', C1818T R: 5'-GATGGCCGAGCTCTTGAAAG3' and G395A F: 5'-CAGTCCCAACGCAACCCATA-3', G395A R: 5'TCAGGTTCATTCTCTTTGCCT- 3 '. The length of the PCR products for C1818T and G395A polymorphisms were $401 \mathrm{bp}$ and $421 \mathrm{bp}$. The region containing these polymorphisms was amplified by PCR with initial denaturation at $95^{\circ} \mathrm{C}$ for 5 min and followed by 30 cycles at $95^{\circ} \mathrm{C}$ for $1 \mathrm{~min}, 55^{\circ} \mathrm{C}$ for $1 \mathrm{~min}, 72^{\circ} \mathrm{C}$ for $1 \mathrm{~min}$ and additionally at $72^{\circ} \mathrm{C}$ for $7 \mathrm{~min}$. Sequence PCR for KLOTHO C1818T and G395A was carried out following PCR cleaning by the same forward primers using Big Dye Terminator v3.1 Cycle Sequencing Kit (Applied Biosystems Inc, Foster City, CA, USA). For KLOTHO C1818T and G395A sequence analysis, capillary electrophoresis was performed on an ABI PRISM ${ }^{\circledR} 3100$ Genetic Analyzer (Applied Biosystems).

VDR gene Apal and Taql polymorphisms were determined by PCR-RFLP analysis. The following primer sets were used for the SNPs of the VDR gene Apal F: 5'-CAGAGCATGGACAGGGAGCAAG-3' and Apal R: 5'GCAACTCCTCATGGGCTGAGGTCTCA-3', Taql F: 5' CAGAGCATGGACAGGGAGCAAG-3' and Taql R: $3^{\prime}$ GCAACTCCTCATGGGCTGAGGTCTCA-3'. The length of the PCR products for Apal and Taql polymorphisms were $740 \mathrm{bp}$ and $421 \mathrm{bp}$. The region containing these polymorphisms was amplified by PCR with initial denaturation at $95^{\circ} \mathrm{C}$ for $5 \mathrm{~min}$ and followed by $10 \mathrm{cycles}$ at $94^{\circ} \mathrm{C}$ for $20 \mathrm{sec}, 65^{\circ} \mathrm{C}$ for $50 \mathrm{sec}, 72^{\circ} \mathrm{C}$ for $1 \mathrm{~min}, 25 \mathrm{cycles}$ at $94^{\circ} \mathrm{C}$ for $20 \mathrm{sec}, 63^{\circ} \mathrm{C}$ for $50 \mathrm{sec}, 72^{\circ} \mathrm{C}$ for $1 \mathrm{~min}$ and additionally at $72^{\circ} \mathrm{C}$ for $6 \mathrm{~min}$. The amplified DNA fragments were digested by Apal and Taql restriction enzymes at $37^{\circ} \mathrm{C}$ for $3 \mathrm{~h}$, at $65^{\circ} \mathrm{C}$ for $3 \mathrm{~h}$, respectively. PCR products and restriction fragments were seperated in $2 \%$ agarose gel with ethidium bromide staining by electrophoresis and visualized by BioDoc-lt ${ }^{\circledR}$ Imaging System-UVP. Genotyping for Apal polymorphism was performed as follows; 740 bp for AA genotype, 740, 515, 225 bp for Aa genotype and 515, $225 \mathrm{bp}$ for aa genotype. Genotyping for Taql polymorphism was performed as follows; 495, 245 bp for TT genotype, 495, 290, 245, 205 bp for Tt genotype and 290, 245, 205 bp for tt genotype.

\section{Statistical analysis}

Genotype distribution within the groups of the cases and controls was compared with values predicted by Hardy-Weinberg equilibrium (HWE) using the chi-square test. Continuous variables were expressed as mean $\pm S D$, and the significance level was defined as $p<0.05$. Test for normality was conducted with Kolmogorov-Smirnov test. Demographic and clinical data were compared using Mann-Whitney $U$ test. The difference of allelic and genotypic frequencies between the case and control groups was also estimated by the Pearson's chi-square test and Fisher's exact test. The odds ratios (ORs) and $95 \% \mathrm{Cl}$ for all potential risk factors were calculated by multivariate logistic regression analyses to evaluate the effects of genetic factors and various environmental factors on the presence of CKD. For the multivariate model, hypertension, diabetes, gender, along with C1818T, G395A, Apal, Taql genotype were incorporated into the model as categorical variables, whereas age and BMI were expressed as a continuous variable. SPSS 18.0 software was used to evaluate all statistical analyses.

\section{RESULTS}

\section{Clinical characteristics of the study subjects}

Demographics and clinical characteristics of subjects are shown in Table 1. Compared to controls, BMI, serum creatinine, serum phosphate and PTH were significantly higher; GFR and BMD-Radius were significantly lower in the patient group. Difference in the ratio of insulin resistance between the groups was not statistically significant. 
Table 1: Demographic and clinical characteristics of the participants $(n=208)$

\begin{tabular}{|c|c|c|c|}
\hline & Healthy subjects & CKD patients & $p$-value \\
\hline $\mathrm{N}$ & 104 & 104 & \\
\hline Male/Female, $n$ & $69 / 35$ & $49 / 55$ & $0.005^{*}$ \\
\hline Age, years & $49.1 \pm 10.2$ & $56.8 \pm 12.5$ & $0.000 *$ \\
\hline Diabetes Mellitus (\%) & 0 & $41(39.4)$ & - \\
\hline Hypertension (\%) & 0 & $62(59.6)$ & - \\
\hline Body Mass Index, $\mathrm{kg} / \mathrm{m}^{2}$ & $28.1 \pm 4,9$ & $29.9 \pm 5.3$ & $0.008^{*}$ \\
\hline $\mathrm{GFR}, \mathrm{mL} / \mathrm{min}$ & $111.3 \pm 28.4$ & $38,7 \pm 16,8$ & $0.000 *$ \\
\hline Creatinine, $\mathrm{mg} / \mathrm{dl}$ & $0.8 \pm 0.2$ & $2.6 \pm 1.4$ & $0.000 *$ \\
\hline Calcium, mg/dl & $9.4 \pm 0.5$ & $9 \pm 0.8$ & $0.000 *$ \\
\hline Phosphate, mg/dl & $3.4 \pm 0.5$ & $3.9 \pm 1.1$ & $0.000 *$ \\
\hline Total Cholesterol, & $197.2 \pm 37.2$ & $195 \pm 65.4$ & 0.344 \\
\hline HDL Cholesterol, & $52 \pm 15.8$ & $45.5 \pm 23.8$ & $0.001^{*}$ \\
\hline LDL Cholesterol, & $116.5 \pm 33.2$ & $116 \pm 56.4$ & 0.268 \\
\hline Triglycerides, & $140.2 \pm 70.2$ & $172 \pm 97.1$ & 0.063 \\
\hline Parathyroid Hormone, $\mathrm{pg} / \mathrm{ml}$ & $59.6 \pm 21.3$ & $150.5 \pm 129.4$ & $0.000 *$ \\
\hline Insulin resistance, $\mathrm{uU} / \mathrm{ml}$ & $52 \pm 15.8$ & $46 \pm 23.8$ & $0.001 *$ \\
\hline BMD-Radius $33 \%, \mathrm{~g} / \mathrm{cm}^{2}$ & $0.8 \pm 0.2$ & $0.8 \pm 0.1$ & 0.094 \\
\hline
\end{tabular}

Data are expressed as means \pm SD unless otherwise indicated.

${ }^{*} p<0.05$ was accepted as significant.

\section{Genotype and allele frequencies of KLOTHO and VDR SNPs}

Genotype and allele frequencies of KLOTHO SNPs in the case and the control groups are shown in Table 2. As for CKD patients, the allele frequencies of the C1818T polymorphism of the KLOTHO gene were 0.649 for the $C$ allele and 0.351 for the T allele, and those for the G395A polymorphism were 0.683 for the $\mathrm{G}$ allele and 0.317 for A allele. While the genotype distributions for C1818T SNPs were in HWE $(p=0.73)$, G395A SNPs were not $(p=0.003)$. In healthy subjects, the allele frequency for the T allele in C1818T was 0.370 and for the A allele in G395A was 0.370 .

Table 2: Genotype and Allele Distributions of C1818T and G395A Polymorphisms

\begin{tabular}{|c|c|c|c|c|c|}
\hline \multirow[t]{2}{*}{ Genotypes } & \multirow[t]{2}{*}{ Controls $(n=104)$} & \multirow{2}{*}{$\begin{array}{l}\text { Cases } \\
(n=104)\end{array}$} & \multirow[t]{2}{*}{$p$-value } & OR $(95 \% \mathrm{Cl})$ & \multirow[t]{2}{*}{$p$-value } \\
\hline & & & & Adjusted $^{a, b}$ & \\
\hline C1818T & & & 0.231 & & \\
\hline $\mathrm{CC}$ & $35(33.65 \%)$ & $43(41.3 \%)$ & & $1^{c}$ & \\
\hline $\mathrm{CT}$ & $61(58.65 \%)$ & $49(47.1 \%)$ & & $0.64(0.33-1.24)$ & 0.187 \\
\hline TT & $8(7.7 \%)$ & $12(11.5 \%)$ & & $0.94(0.28-3.09)$ & 0.912 \\
\hline $\mathrm{CT}+\mathrm{TT}$ & $69(66.35 \%)$ & $61(58.6 \%)$ & & $0.69(0.36-1.29)$ & 0.244 \\
\hline C & $131(62.9 \%)$ & $135(59.6 \%)$ & 0.683 & $1^{c}$ & \\
\hline \multirow[t]{2}{*}{$\mathrm{T}$} & 77(37.1\%) & $73(40.4 \%)$ & & $1.08(0.72-1.62)$ & 0.759 \\
\hline & HWE $p=0.008$ & HWE $p=0.73$ & & & \\
\hline G395A & & & 0.302 & & \\
\hline GG & $36(34.6 \%)$ & $42(40.4 \%)$ & & $1^{c}$ & \\
\hline $\mathrm{GA}$ & $59(56.7 \%)$ & $58(55.8 \%)$ & & $0.69(0.36-1.34)$ & 0.277 \\
\hline AA & $9(8.7 \%)$ & $11(10.6 \%)$ & & $0.22(0.05-0.98)$ & 0.046 \\
\hline $\mathrm{GA}+\mathrm{AA}$ & $68(65.4 \%)$ & $4(3.8 \%)$ & & $0.65(0.34-1.23)$ & 0.188 \\
\hline G & $131(62.9 \%)$ & $142(68.3 \%)$ & 0.832 & $1^{\mathrm{c}}$ & \\
\hline \multirow[t]{2}{*}{ A } & $77(37.1 \%)$ & $80(31.7 \%)$ & & $1.04(0.70-1.54)$ & 0.842 \\
\hline & HWE $p=0.03$ & HWE $p=0.003$ & & & \\
\hline
\end{tabular}

a Compared with $C C$ versus $C T, T T$, and $C T+T T$.

${ }^{b}$ Compared with $G G$ versus $G A, A A$, and $G A+A A$.

'Reference genotype/allele. OR adjusted for age, gender and BMI.

Genotype and allele frequencies of VDR SNPs in the case and the control groups are shown in Table 3. As for CKD patients, the allele frequencies of the Apal polymorphism of the VDR gene were 0.678 for the A allele and 0.322 for the a allele; and those for the Taql polymorphism were 0.697 for the $T$ allele and 0.303 for $t$ allele. While the genotype distributions for Taq I SNPs were in HWE ( $p=0.498)$, Apal SNPs were not $(p=0.004)$. In healthy subjects, the allele frequency for the a allele in Apal was 0.404 and for the $t$ allele in Taql it was 0.322 . While the genotype distributions for Taql SNPs were in HWE $(p=0.32)$,
The allele frequencies of C1818T and those of the G395A were not significantly different from CKD patients $(p=0.683$ and $p=0.832$, respectively). The genotype distributions for C1818T and G395A SNPs were not HWE ( $p=0.008$, $p=0.03$ ). There was no statistically significant difference between the groups in terms of genotype and allele frequencies. We performed multivariate logistic regression analysis to evaluate effects of C1818T and G395A polymorphisms on risk of developing CKD. There was no association detected between C1818T ve G395A polymorphisms and the CKD risk (Table 2). 
Table 3: Genotype and Allele Distributions of Apal and Taql Genotypes

\begin{tabular}{|c|c|c|c|c|c|}
\hline \multirow[t]{2}{*}{ Genotypes } & \multirow[t]{2}{*}{ Controls $(n=104)$} & \multirow[t]{2}{*}{ Cases $(n=104)$} & \multirow[t]{2}{*}{$p$-value } & OR $(95 \% \mathrm{Cl})$ & \multirow[t]{2}{*}{$p$-value } \\
\hline & & & & Adjusted $^{a, b}$ & \\
\hline Apal & & & 0.018 & & \\
\hline$A A$ & $61(58.6 \%)$ & $44(42.3 \%)$ & & $1^{c}$ & \\
\hline $\mathrm{Aa}$ & $19(18.3 \%)$ & $36(34.6 \%)$ & & $2.52(1.12-5.68)$ & 0.025 \\
\hline aa & $24(23.1 \%)$ & $24(23.1 \%)$ & & $1.82(0.79-4.23)$ & 0.161 \\
\hline $\mathrm{Aa}+\mathrm{aa}$ & $43(41.4 \%)$ & $60(57.7 \%)$ & & $2.1(1.14-3.88)$ & 0.018 \\
\hline$A$ & $141(67.8 \%)$ & $124(59.6 \%)$ & 0.083 & $1^{c}$ & \\
\hline \multirow[t]{2}{*}{ a } & $67(32.2 \%)$ & $84(40.4 \%)$ & & $0.70(0.46-1.04)$ & 0.103 \\
\hline & HWE $p=0.000$ & HWE $p=0.004$ & & & \\
\hline Taql & & & 0.902 & & \\
\hline $\mathrm{TT}$ & $50(48.1 \%)$ & $52(50 \%)$ & & $1^{\mathrm{c}}$ & \\
\hline $\mathrm{Tt}$ & $41(39.4 \%)$ & $41(39.4 \%)$ & & $0.79(0.38-1.63)$ & 0.516 \\
\hline $\mathrm{tt}$ & $13(12.5 \%)$ & $11(10.6 \%)$ & & $1.25(0.43-3.64)$ & 0.679 \\
\hline$T t+t t$ & $54(51.9 \%)$ & $52(50 \%)$ & & $0.99(0.53-1.83)$ & 0.962 \\
\hline $\mathrm{T}$ & $141(67.8 \%)$ & $145(69.7 \%)$ & 0.672 & $1^{c}$ & \\
\hline \multirow[t]{2}{*}{$\mathrm{t}$} & $67(32.2 \%)$ & $63(30.3 \%)$ & & $1.09(0.72-1.65)$ & 0.751 \\
\hline & HWE $p=0.320$ & HWE $p=0.498$ & & & \\
\hline
\end{tabular}

${ }^{a}$ Compared with $A A$ versus $A a$, aa, and $A a+a a$

${ }^{b}$ Compared with $\mathrm{TT}$ versus $\mathrm{Tt}$, $\mathrm{tt}$, and $\mathrm{Tt}+\mathrm{tt}$.

${ }^{\mathrm{C}}$ Reference genotype/allele. OR adjusted for age, gender and BMI.

Genotype distribution of KLOTHO and VDR gene in CKD patients with different clinical phenotypes.

Genotype distributions were compared in subgroups of CKD patients with different clinical phenotypes. The results are summarized in Table 4.
We did not found a significant association between polymorphisms of VDR (Apal, Taql) and KLOTHO (C1818T, G395A) gene and hypertension and diabetes risk in CKD patients. The comparison of subgroups with normotensive/hypertensive and non-diabetic/diabetic kidney disease did not indicate a difference in genotype distribution.

Table 4: Genotype distributions of KLOTHO and VDR SNPs in CKD patients classified according to hypertension and diabetes status.

\begin{tabular}{|c|c|c|c|c|c|c|c|c|}
\hline \multirow[t]{2}{*}{ Genotypes } & \multirow{2}{*}{$\begin{array}{l}\text { Normotensive } \\
(n=42)\end{array}$} & \multirow{2}{*}{$\begin{array}{l}\text { Hypertensive } \\
(n=62)\end{array}$} & \multirow{2}{*}{$\begin{array}{l}\text { OR (95\% Cl) } \\
\text { Adjusted }^{a}\end{array}$} & \multirow[t]{2}{*}{$p$-value } & \multirow{2}{*}{$\begin{array}{l}\text { Non-Diabetic } \\
(n=41)\end{array}$} & \multirow{2}{*}{$\begin{array}{l}\text { Diabetic } \\
(n=63)\end{array}$} & \multirow{2}{*}{$\begin{array}{l}\text { OR }(95 \% \mathrm{Cl}) \\
\text { Adjusted }^{b}\end{array}$} & \multirow[t]{2}{*}{$p$-value } \\
\hline & & & & & & & & \\
\hline \multicolumn{9}{|l|}{ Apal } \\
\hline$A A$ & $17(40.5)$ & $27(43.5)$ & $1^{c}$ & & $28(44.4)$ & $16(39)$ & $1^{\mathrm{c}}$ & \\
\hline $\mathrm{Aa}$ & $12(28.6)$ & $24(38.7)$ & $1.26(0.41-3.88)$ & 0.682 & $17(27)$ & $19(46.3)$ & $2.16(0.70-6.61)$ & 0.179 \\
\hline aa & $13(31)$ & $11(17.7)$ & $0.98(0.3-3.26)$ & 0.975 & $18(28.6)$ & $6(14.6)$ & $0.67(0.17-2.6)$ & 0.561 \\
\hline \multicolumn{9}{|l|}{ Taql } \\
\hline TT & $26(61.9)$ & $26(41.9)$ & $1^{c}$ & & $34(54)$ & $18(43.9)$ & $1^{c}$ & \\
\hline $\mathrm{Tt}$ & $12(28.6)$ & $29(46.8)$ & $1.87(0.66-5.28)$ & 0.240 & $23(36.5)$ & $18(43.9)$ & $0.93(0.32-2.71)$ & 0.894 \\
\hline $\mathrm{tt}$ & $4(9.5)$ & $7(11.3)$ & $1.66(0.37-7.41)$ & 0.507 & $6(9.5)$ & $5(12.2)$ & $1.33(0.28-6.41)$ & 0.723 \\
\hline \multicolumn{9}{|l|}{$\mathrm{C} 1818 \mathrm{~T}$} \\
\hline $\mathrm{CC}$ & $20(47.6)$ & $23(37.1)$ & $1^{\mathrm{c}}$ & & $30(47.6)$ & $13(31.7)$ & $1^{c}$ & \\
\hline $\mathrm{CT}$ & $18(42.9)$ & $31(50)$ & $1.3(0.52-3.23)$ & 0.578 & $29(46)$ & $20(48.8)$ & $1.41(0.55-3.64)$ & 0.476 \\
\hline TT & $4(9.5)$ & $8(12.9)$ & $1.18(0.24-5.83)$ & 0.840 & $4(6.3)$ & $8(19.5)$ & $2.29(0.46-11.34)$ & 0.310 \\
\hline \multicolumn{9}{|l|}{ G395A } \\
\hline GG & $22(52.4)$ & $20(32.3)$ & $1^{\mathrm{c}}$ & & $26(41.3)$ & $16(39)$ & $1^{c}$ & \\
\hline GA & $18(42.9)$ & $40(64.5)$ & $2.21(0.88-5.57)$ & 0.092 & $36(57.1)$ & $22(53.7)$ & $0.66(0.25-1.76)$ & 0.400 \\
\hline$A A$ & $2(4.8)$ & $2(3.2)$ & $0.83(0.08-8.4)$ & 0.878 & $1(1.6)$ & $3(7.3)$ & $1.11(0.08-15.05)$ & 0.939 \\
\hline
\end{tabular}

${ }^{\mathrm{a}}$ OR adjusted for age, gender, BMI, diabetes. ${ }^{\mathrm{b}}$ OR adjusted for age, gender, BMI, hypertension. ${ }^{\mathrm{c}}$ Reference genotype/allele.

\section{DISCUSSION}

CKD is a common social health problem which leads to high costs and has a poor prognosis. Furthermore, the incidence and prevalence of the disease is gradually increasing. In many studies, it is reported that chronic kidney disease susceptibility genes affect prognosis of the disease together with the environmental and hereditary factors (2).

Klotho expression in kidneys is thought to be associated with the poor prognosis of the CKD since its expression decreases in CKD patients and mice with diabetic nephropathy. Decreased expression of Klotho leads to the deterioration of the Klotho expression and renal function and thus it fastens the renal damage (17). In this study, KLOTHO gene G395A and C1818T polymorphisms were genotyped. According to our results, the allele and genotype frequencies of C1818T and those of the G395A were not significantly different from CKD patients Shimoyama and colleagues showed that genotype frequencies of G395A were $68.1 \%$ GG, 30.2\% GA and $1.7 \%$ AA, genotype frequencies of C1818T were $68.1 \%$ CC, $28.5 \%$ CT and 3.4\% TT in 219 Japanese hemodialysis patients (4). Kim et al. indicated that genotype frequencies of G395A were $72.2 \% \mathrm{GG}, 24.6 \% \mathrm{GA}$ and $3.2 \% \mathrm{AA}$. In this regard, our findings were in line with the findings of Kim et al. (29).
KLOTHO gene was discovered by Kuro et al. during the developmental process of hypertensive transgenic mice models (3). It has been shown in studies that Klotho is associated with hypertension (5) and diabetic nephropathy (18).

Klotho is shown to have roles in various processes such as oxidative stress apoptosis, inflammation and fibrosis which can negatively affect the pathology. Moreover, these mechanisms have not yet been clarified (17).

Today, it is well known that the frequency of the hypertension increases as the renal failure progresses and uncontrolled hypertension fastens the renal failure progression (19). Wang et al. performed a study with 215 patients with hypertension and 220 patients without hypertension from the Han Chinese society (9). According to their results, it was stated that patients who carry the A allele of the KLOTHO G395A polymorphism had higher hypertension compared to the control group. Shimoyama et al. performed a study with 476 healthy Japanese, and they showed that there was no difference between people with/without carrying KLOTHO gene G395A polymorphism (4). Rhee et al. found that systolic blood pressure of the Korean women was higher in individuals carrying the A allele of the KLOTHO G395A polymorphism compared to the ones who did not carry the A allele (30). In this regard, our study is in line with the study performed by Shimoyama et al(4). 
Recently, the number of patients who have renal failure due to the diabetes is increasing throughout the world. Hyperglycemia which is developed in diabetic patients deteriorates the vessels and leads to the renal damage (20). The roles of Klotho in the glucose control, diabetes and phosphate mechanism have not yet been investigated (21). In a study which was performed with 804 adults living in a nursing home, it was observed that the levels of serum Klotho were gradually decreasing in individuals older than 65 years old (22). KLOTHO is a member gene for T2DM due to its importance in the insulin signalization as shown in murine models and it plays a potential role during the life (23). Shimoyama et al. performed a study in which they included 476 healthy Japanese in order to determine the association between the KLOTHO gene $\mathrm{C} 1818 \mathrm{~T}$ and $\mathrm{G} 395 \mathrm{~A}$ polymorphisms and fasting glucose levels (4). According to their findings, they showed that fasting glucose levels were higher in individuals who were carrying G395A polymorphism A allele compared to ones who were carrying GG genotype. It is also higher in individuals who were carrying C1818T polymorphisms T allele compared to ones who were carrying CC genotype. Unlike the related literature findings, we did not detect any relationship between $\mathrm{C} 1818 \mathrm{~T}$ and G395A polymorphisms and diabetes development.

Progression of the CKD is shown to be associated with Vitamin $D$ deficiency (24). In studies, it has been stated that Vitamin $D$ is an important regulator in immune, renal and cardiovascular systems. Furthermore, it has been specified that Vitamin D has regulatory roles in the Renin Angiotension System (RAS) in CKD patients (24). According to our findings, in terms of VDR gene Apal polymorphisms genotype distribution, Aa genotype was significantly higher in case group compared to control group $(p=0.018)$. Even though A allele frequency was higher in control group compared to the patient group $(O D=$ $0.701 \mathrm{Cl}=0.469-1.048)$, this difference was not statistically significant $(p=0.083)$. There was no difference between the groups in terms of $V D R$ gene Taql polymorphism genotype distributions $(\mathrm{p}=0.902)$.

VDR gene has an important role in the regulation of the RAS which is crucial in blood pressure regulation (25). Vural et al. performed a study with 100 Turkish patients with hypertension and diabetes and 100 Turkish healthy controls in order to evaluate the VDR gene Taql polymorphism, and they showed that the genotype distributions were $51 \% \mathrm{TT}, 46 \% \mathrm{Tt}$ and $3 \% \mathrm{tt}$ in the patient group and $35 \% \mathrm{TT}, 49 \% \mathrm{Tt}$ and $16 \% \mathrm{tt}$ in the control group (26). Even though they found the T allele frequency in the patient group was higher than the control group $(p<0.05)$, there was no difference between hypertension and diabetes patients and control individuals in terms of the VDR gene Taql polymorphism allele frequency. In line with the related literature, we did not detect any difference between Apal and Taql polymorphisms and hypertension development risk.

Vitamin $D$ has an important immune regulatory feature and it can play a role in the T1DM and T2DM etiology via affecting the insulin secretion. VDR polymorphisms can have roles in the T2DM pathogenesis by influencing the secretion capacity of $\beta$-cells (10). In studies, a relationship between T1DM, T2DM and some allelic variants of VDR gene has been identified $(11,27)$. In French population, Taql genotype is associated with T2DM, obesity and early onset of the diabetes (28). In Caucasian population, an association between glucose intolerance and Apal polymorphisms GG genotype was detected in patients with T2DM (13). These findings show that VDR gene is a member gene for both of the two diabetes types. Dilmec et al. (2010) found that allele frequencies were $9.7 \% \mathrm{GG}, 52.8 \% \mathrm{GT}$ and $37.5 \% \mathrm{TT}$ for Apal (g.59979G $>$ T) SNP and $45.8 \% \mathrm{TT}, 34.7 \% \mathrm{TC}$ and $19.4 \% \mathrm{CC}$ for Taql (g.60058T>C) in 72 Turkish T2DM patients. They did not detect a significant difference between allele and genotype frequencies of both groups. Even though the relationship between the diabetes and VDR polymorphisms was investigated in some population studies, we did not detect any association between Apal and Taql polymorphisms and diabetes development risk which was also shown in the study performed by Dilmec et al(10).

According to our knowledge, this study is the first one which has been performed on KLOTHO and VDR gene polymorphisms and CKD in Turkish population. In our study, we did not support the idea that there is a relationship between CKD and KLOTHO gene polymorphisms in the Turkish population. Additionally, in our study, VDR gene Apal polymorphisms Aa genotype was found higher in case group compared to control group, and individuals who were carrying this genotype were thought to have higher risks in terms of CKD development. Although our study is a comprehensive study, there are also some limitations. The first limitation is that we had a comparatively low sample size in terms of patient and control groups. Secondly, CKD is a heterogeneous disease which is affected by both genetic and environmental factors. Therefore, we believe that our findings should be supported by further studies investigating more polymorphisms and having well matched and large number of cases and controls.

\section{Acknowlegement}

This study was supported by the Afyon Kocatepe University Research Fund with code number 10.TIP.24.

\section{Conflict of interest}

No conflict of interest was declared by the authors.

\section{REFERENCES}

1. Akpolat T, Utaş C, Süleymanlar G. Nefroloji el kitabı. 3. Baskı, İstanbul, Turkey: Nobel Tıp Kitabevi; 2000.

2. Yoshida T, Kato K, Fujimaki T, Yokoi K, Oguri M, Watanabe S, et al. Association of genetic variants with chronic kidney disease in Japanese individuals. Clin J Am Soc Nephrol 2009, 24:883-90.

3. Kuro-O M. Klotho. Eur J Physiol 2010;459:333-43.

4.Shimoyama Y, Nishio K, Hamajima N, Niwa T. KLOTHO gene polymorphisms G-395A and $\mathrm{C} 1818 \mathrm{~T}$ are associated with lipid and glucose metabolism, bone mineral density and systolic blood pressure in Japanese healthy subjects. Clin Chim Acta 2009;406:134-8.

5. Rhee EJ, Oh KW, Lee WY, Kim SY, Jung CH, Kim BJ, et al. The differential effects of age on the association of KLOTHO gene polymorphisms with coronary artery disease. Metabolism 2006;55:1344-1351.

6. Kawano K, Ogata N, Chiano M, Molloy H, Kleyn P, Spector TD, et al. Klotho gene polymorphisms associated with bone density of aged postmenopausal women. J Bone Miner Res 2002;17:1744-51.

7. Valdivielso JM, Fernandez E. Vitamin D receptor polymorphisms and diseases. Clin Chim Acta 2006;371:1-12.

8. Martin RJ, Mcknight AJ, Patterson CC, Sadlier DM, Maxwell AP, Warren 3/UK GoKinD Study Group. A rare haplotype of the vitamin $D$ receptor gene is protective against diabetic nephropathy. Nephrol Dial Transplant 2010;25:497-503.

9. Wang $\mathrm{HL}, \mathrm{Xu} \mathrm{Q}$, Wang $\mathrm{Z}$, Zhang $\mathrm{YH}, \mathrm{Si} \mathrm{LY}$, Li XJ, et al. A potential regulatory single nucleotide polymorphism in the promoter of the Klotho gene may be associated with essential hypertension in the Chinese Han population. Clin Chim Acta 2010;411:386-90.

10. Dilmec F, Uzer E, Akkafa F, Kose E, Van Kuilenburg AB. Detection of VDR gene Apal and Taql polymorphisms in patients with type 2 diabetes mellitus using PCR-RFLP method in a Turkish population. J Diabetes Complication 2010;24:186-91.

11. Skrabic V, Zemunik T, Situm M, Terzic J. Vitamin D receptor polymorphism and susceptibility to type 1 diabetes in the Dalmatian population. Diabetes Res Clin Pract 2003;59:31-5

12. Langdahl BL, Gravholt $\mathrm{CH}$, Brixen K, Eriksen EF. Polymorphisms in the vitamin D receptor gene and bone mass, bone turnover and osteoporotic fractures. Eur J Clin Invest 2000;30:608-17

13. Oh JY, Barrett-Connor E. Association between vitamin D receptor polymorphism and type 2 diabetes or metabolic syndrome in community-dwelling older adults: The Rancho Bernardo Study. Metabolism 2002;51:356-9.

14. Buyru N, Tezol A, Yosunkaya-Fenerci E, Dalay N. Vitamin D receptor gene polymorphisms in breast cancer. Exp Mol Med 2004:35:550-5.

15. Lurie G, Wilkens LR, Thompson PJ, McDuffie KE, Carney ME, Terada KY, et al. Vitamin D receptor gene polymorphisms and epithelial ovarian cancer risk. Cancer Epidemio Biomarkers Prev 2007;16:2566-71.

16. Yokoyama K, Shigematsu T, Tsukada T, Ogura Y, Takemoto F, Hara S, et al. Apa polymorphism in the vitamin $D$ receptor gene may affect the parathyroid response in Japanese with end-stage renal disease. Kidney Int 1998;53:454-8.

17. Ko GJ, Lee EA, Jeon US, Pyo HJ, Chin HJ, Chae DW, et al. The association of Klotho polymorphism with disease progression and mortality in IgA nephropathy. Kidney Blood Press Res 2012;36:191-9.

18. Lee EY, Kim SS, Lee JS, Kim IJ, Song SH, Cha SK, et al. Soluble $\alpha$-klotho as a novel biomarker in the early stage of nephropathy in patients with type 2 diabetes. PLoS One 2014;9:e102984.

19. Sezer S, Külah E, Özdemir FN. Hipertansiyonun renal komplikasyonlar ve böbrek hastalığının progresyonundaki rolü. Turk Neph Dial Transpl 2003;12:67-73.

20. Süleymanlar $G$, Serdengeçti $K$, Erek $E$. Türkiye'de son dönem böbrek yetmezliğin etyolojisi. Turkiye Klinikleri J Int Med Sci 2005;1:1-8.

21. Razzaque MS. Role of Klotho in energy metabolism. Nat Rev Endocrinol 2012:8:579-87. 22. Semba RD, Cappola AR, Sun K, Bandinelli S, Dalal M, Crasto C, et al. Plasma klotho and mortality risk in older community-dwelling adults. J Gerontol A Biol Sci Med Sci 2011;66:794 800.

23. Kurosu H, Yamamoto M, Clark JD, Pastor JV, Nandi A, Gurnani P, et al. Suppression of aging in mice by the hormone Klotho. Science 2005;309:1829-33.

24. Williams S, Malatesta K, Norris K. Vitamin D and Chronic Kidney Disease. Ethn Dis 2009;19 (4 Suppl 5):5-8-11.

25. Swapna N, Mohana Vamsi U, Usha G, Padma T. Risk conferred by Fokl polymorphism of vitamin D receptor (VDR) gene for essential hypertension. Indian J Hum Genet 2011;17:201 6.

26. Vural HC, Maltas E. RT-qPCR assay on the vitamin D receptor gene in type 2 diabetes and hypertension patients in Turkey. Genet Mol Res 2012;11:582-90.

27. Malecki MT, Frey J, Moczulski D, Klupa T, Kozek E, Sieradzki J. Vitamin D receptor gene polymorphisms and association with Type 2 diabetes mellitus in a Polish population. Exp Clin Endocrinol Diabetes 2003;111:505-9.

28. Ye WZ, Reis AF, Dubois-Laforgue D, Bellanné-Chantelot C, Timsit J, Velho G. Vitamin D receptor gene polymorphisms are associated with obesity in Type 2 diabetic subjects with early age of onset. Eur J Endocrinol 2001;145:181-6.

29. Kim Y, Jeong SJ, Lee HS, Kim EJ, Song YR, Kim SG, et al. Polymorphism in the promoter region of the Klotho gene (G-395A) is associated with early dysfunction in vascular access in hemodialysis patients. Korean J Intern Med 2008;23:201-7.

30. Rhee EJ, Oh KW, Yun EJ, Jung CH, Lee WY, Kim SW, et al. Relationship between polymorphisms G-395A in promoter and C1818T in exon 4 of the KLOTHO gene with glucose metabolism and cardiovascular risk factors in Korean women. J Endocrinol Invest 2006;29:613-8 